Article

\title{
Destination Image Analytics Through Traveller-Generated Content
}

\author{
Estela Marine-Roig
}

Serra Hunter Fellow, University of Lleida, 25003 Catalonia, Spain; estela.marine@aegern.udl.cat; Tel.: +34-973-703-338

Received: 8 May 2019; Accepted: 17 June 2019; Published: 19 June 2019

\begin{abstract}
The explosion of content generated by users, in parallel with the spectacular growth of social media and the proliferation of mobile devices, is causing a paradigm shift in research. Surveys or interviews are no longer necessary to obtain users' opinions, because researchers can get this information freely on social media. In the field of tourism, online travel reviews (OTRs) hosted on travel-related websites stand out. The objective of this article is to demonstrate the usefulness of OTRs to analyse the image of a tourist destination. For this, a theoretical and methodological framework is defined, as well as metrics that allow for measuring different aspects (designative, appraisive and prescriptive) of the tourist image. The model is applied to the region of Attica (Greece) through a random sample of 300,000 TripAdvisor OTRs about attractions, activities, restaurants and hotels written in English between 2013 and 2018. The results show trends, preferences, assessments, and opinions from the demand side, which can be useful for destination managers in optimising the distribution of available resources and promoting sustainability.
\end{abstract}

Keywords: destination image; user-generated content; online travel review; big data analytics; opinion mining; sentiment analysis; resource optimisation; place sustainability; TripAdvisor; Greek Attica

\section{Introduction}

Nations, states, cities, and regions commit considerable effort and funds to improving their tourist destination image (TDI) and attractiveness [1]. Due to growing competitiveness, promotion strategists need more precise information about the diversity of responses to TDI [2]. The image of a city [3], country [4], region [5], or tourist destination [6-8] has been the subject of constant study for more than half a century in countless scientific publications. This great production on destination image has led to systematic reviews [9-12] and meta-analyses [13,14]. The great success of this concept may be because the authors agree that image - projected and perceived-plays a crucial role in decision-making regarding selecting a holiday destination $[7,9,15,16]$. Consequently, some authors $[17,18]$ theorised about the image formation process. The agents of image formation can be divided into three groups according to the origin of the sources [18,19]: induced (emanating from the destination promoters), organic (transmitted between individuals) and autonomous (produced independently of the previous ones).

Among the organic agents, along with the experience itself, is the opinion of users and consumers that spreads through word-of-mouth marketing (WoM), in conversations with relatives, friends, colleagues, or acquaintances. From the proliferation of user-generated content (UGC) disseminated through social media, we speak about electronic WoM communication (eWoM). Opinions of other users and consumers transmitted through both WoM and eWoM, have become the main sources of secondary information (not including the primary source of own experience) in the process of procuring goods or contracting services online. 
In travel, hospitality and tourism, experiences shared through social media have been increasing [20] as well as consultation (before and during the trip) and consideration of content generated by other travellers. Within traveller-generated content (TGC), some authors have used travel-related forums [21,22], tweets [23], Facebook posts [24], multiple social media [25] and online photographs [26-28] to deduce TDI aspects, but most have focused on travel blogs [29] and online travel reviews (OTR) [30]. It is worth highlighting the transition from travel blogs to OTRs. OTRs have grown dramatically, while many portals that hosted travel blogs have disappeared. For example, the portal TripAdvisor stored 10 million OTRs in 2007 [30], and it has already exceeded 700 million, covering more than 8 million tourist resources worldwide [31]. This abundance of first-hand, spontaneous, disinterested, and freely available online information has led many researchers to choose OTRs as a data source [32,33]. It has gone from analysing a few hundred opinions obtained through expensive surveys to freely dispose of hundreds of thousands of OTRs about places or tourist resources of a destination. For example, TripAdvisor currently stores over 150,000 opinions and 100,000 photographs on the Basilica of the Sagrada Familia in Barcelona.

The figures above and other more spectacular in the field of UGC, and social media (Facebook, Twitter, etc.) gave rise to the link between their analysis and that of big data [34-36]. Therefore, much research has been devoted to social media analytics in general [37-39] and tourism analytics in particular [40-42].

Regarding the percentage of users who consulted the opinions of other travellers spread through WoM and eWoM, the following surveys can be highlighted:

- The European Union surveyed more than 30,000 Europeans from different social and demographic groups [43]. One question was: "Which of the following information sources do you think is most important when you make a decision about your travel plans? (Maximum three answers)". They were, in the first two positions, WoM (recommendations of friends, colleagues or relatives) with $51 \%$ followed by eWoM (websites collecting and presenting comments, opinions and ratings from travellers-OTRs) with $34 \%$.

- In another case confined to Britain, more than 11,000 foreign visitors were surveyed [44]. In response to the question: "Thinking about your holiday in Britain, which of the following information sources influenced your choice of destination?", 40\% used WoM (conversations with friends or family) and 30\% eWoM (OTRs), slightly behind search engines and price comparison portals.

- Recently, results similar to those above were obtained in a survey of more than 2,000 Americans who had travelled for pleasure in the past 12 months [45]. However, eWoM had more weight than WoM. To the question: "In the past 12 months, which of these Internet technologies or services have you used to help plan your leisure travel? (Select all that apply)", $58.2 \%$ had used eWoM (TGC) and $45.6 \%$ WoM (opinions of friends, colleagues or relatives). Of the travellers who used eWoM, 32.5\% consulted OTRs about hotels, 30.8\% about restaurants or activities, and $29.6 \%$ about destinations.

Previous surveys have highlighted organic information sources, transmitted through WoM and eWoM. These sources are the most consulted by potential tourists. These results are crucial to demonstrate that TGC is an agent of the destination image construction, because travel blogs and OTRs are expressions of the image perceived (and transmitted) by visitors [46]. Besides, TGC has to be consulted by other tourists or prospective tourists to be part of the projected image and close the circle of Figure 1. It is noteworthy that the aforementioned survey on TGC usage [45] coincides with another that was conducted ten years earlier [30], in the sense that the respondents considered extremely important or very important, first "Where to stay"; second, "Where to eat"; and, third, "What to do". Over a few years, TGC and social media have reversed in priority between sources. Late last century, tourist offices, tour operators and travel agencies were protagonists in constructing the projected image [47]; induced sources, especially destination marketing and management organisations (DMO), had a high penetration in the market, while organic sources had minimal [18]. 
From the perspective of scientific literature, in principle, it was questioned whether prospective travellers intended to use TGC in planning their trips [48]. There were also doubts about the credibility of TGC, especially with hotel OTRs [49]. There are already numerous studies that show the usefulness of TGC [50]. By way of example, the following, based on surveys, can be cited: one, on Turkish users [51], showed the validity of TGC as a source in the search for information related to the trip and, more broadly, in the planning process thereof. Another, on visitors from New Zealand [52], revealed that perceived usefulness and empowerment led to the use of TGC to plan the trip. A third, about Chinese travellers [53], showed that eWoM had a significant utility and influence in the planning and decision making related to the trip. The influence of OTRs in travel decision making has also been demonstrated through artificial intelligence methodologies [54].

Moreover, image is a qualifying and amplifying determinant of destination competitiveness and sustainability $[1,55]$. DMOs should be caretakers of the image and resources of destinations through policies and incentives that facilitate developing products, desirable from the demand side, but that do not endanger local resources [56]. In this vein, "The very existence of tourism and sustained competitiveness depends on the availability of resources and the degree to which these resources are bundled to meet visitor expectations and needs at the destination" [57] (p. 100). Consequently, DMOs need to know the TDI, from the viewpoint of their visitors, to properly manage available resources. However, literature on this perspective is scarce [58]. These authors assessed the destination image from the tourists' viewpoint through 203 TripAdvisor OTRs. Despite several studies applying big data analytics on OTRs about accommodations, restaurants and tourist attractions, no such studies have integrated the analysis of different types of tourism resources to measure the cognitive, affective and conative components of TDIs.

In response, the chief objective of the study presented here was to propose a theoretical and methodological framework to measure TDIs by analysing TGC. The novelty of the study stems from its integration of big data from OTRs about various kinds of tourism resources (attractions, travel-related activities, hotels and restaurants) to measure three components of TDIs according to common metrics. This proposed model of big data analytics applies to a Greek region, Attica, where the most striking and complete ancient Greek monumental complex is located [59]. To explore which tourist resources are most popular and best valued by tourists, a random sample of 300,000 TripAdvisor OTRs $(100,000$ from the attractions section, 100,000 from the restaurants section, and 100,000 from the hotels section) are analysed. The results, based on visitors' needs, preferences and opinions, can be useful to DMOs to optimise deployment of available resources and promote sustainability.

\section{Image of a Tourist Destination}

The images are of paramount importance because they transpose the representation of an area inside the mind of potential tourists and give them a preliminary idea of the destination [60]. The TDI has received numerous definitions throughout its history. The most commonly used terms in its definition have been [61]: impression (45\%), perception $(27 \%)$, belief $(18 \%)$, idea $(18 \%)$, and representation $(15 \%)$. One of the most cited by scientific doctrine is that which says that image can be defined as the sum of beliefs, ideas and impressions that a person has about a tourist destination [15]. Researchers have distinguished projected images from perceived images [62].

Projected images can be conceived as the ideas and representations of destinations that are available for tourists' consideration [63]. The authors agree on the subjectivity of the perceived image. Human behaviour is based more on image than on objective reality because what an individual believes to be true, in fact, is true for him or her [64]. From this perspective, the TDI is defined as the subjective interpretation of reality made by a tourist [65] or a partial, simplified, idiosyncratic, and distorted representation that is not necessarily isomorphic in relation to the real-world environment [66]. In other cases, its complexity is highlighted by defining the TDI as a sum of associations and pieces of information connected to a destination that would include multiple destination components 
and personal perception [67]. In the following sections, the multiple factors that influence image construction and the components that make it up will be explained.

\subsection{Image Building}

The image of a town is a multidimensional and complex construct [68]. The image of a pleasure travel destination is a global concept (gestalt). It is a holistic construct that, to a greater or lesser extent, derives from attitudes regarding the perception of the destination's tourist attributes [69].

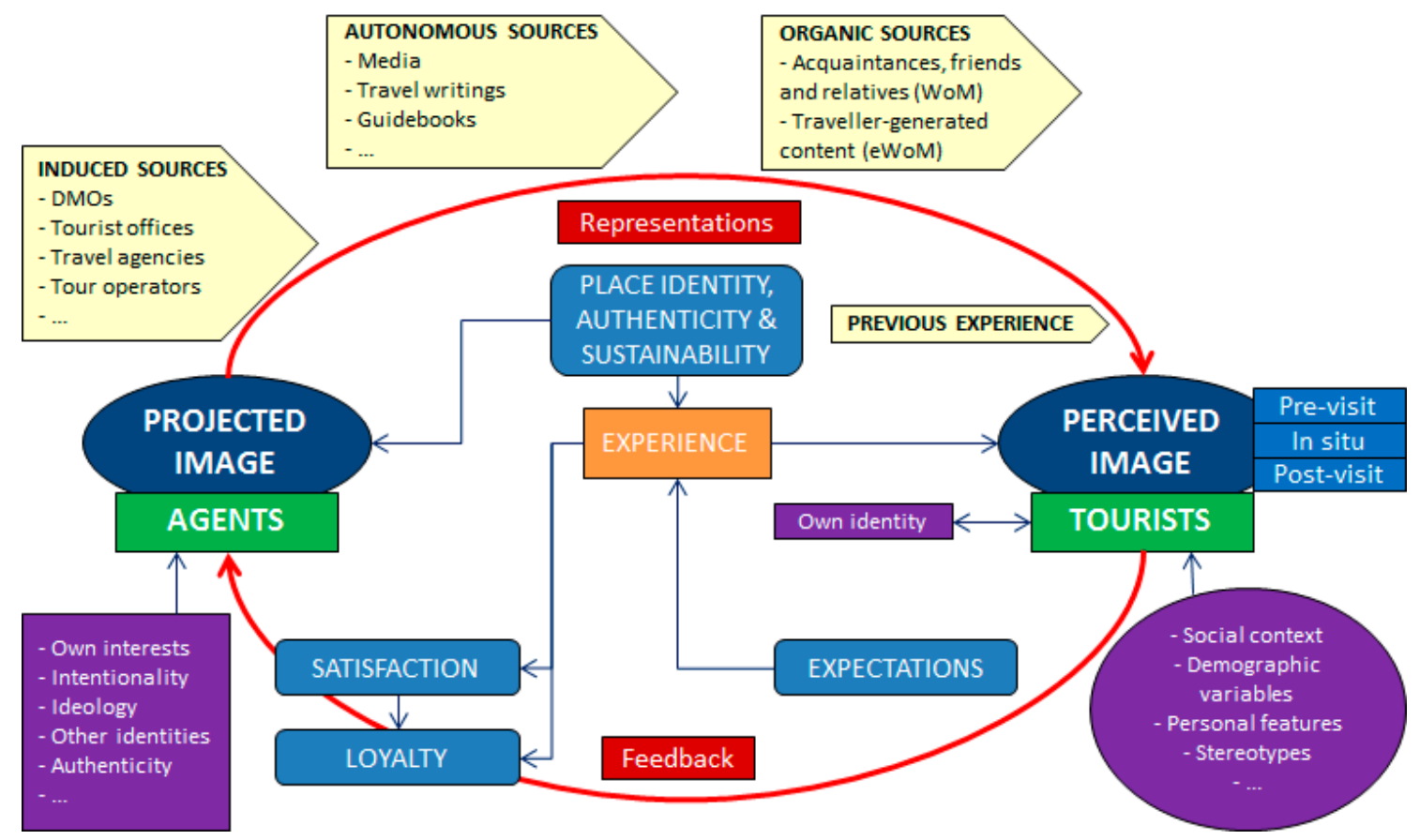

Figure 1. Circle of image construction from a holistic perspective, derived from Marine-Roig [70].

In Figure 1, one can observe agents, constructs, information sources, and major variables involved in the construction of the image. These elements are interrelated in a circle. At opposite points of their diameter, agents project the image and tourists perceive. The perceived image may vary according to the stage of the trip (before, during and after). The representations of the tourist destination are in the arc Agents-Tourists, and the opinions of visitors (feedback) are in the arc Tourists-Agents. The visitor's lived experience is in the centre of the circle. Furthermore, in Figure 1, one can observe some of the variables that explain the subjectivity of the image perceived by tourists and discordance of representations in the projected image by the agents. Next, the most important aspects of the scheme are explained.

- Information sources. The representations come from two sources of information: primary and secondary. Secondary sources are grouped into three types: induced, autonomous and organic [18]. In the organic sources of Gartner, the TGC diffused through eWoM has been added [71] and previous experience has been segregated. The latter is distinguished by being a primary source [72] and enjoying the highest credibility for tourists since it is based on information personally acquired in a previous trip to the area.

- Expectations. The lived experience has as antecedent expectations that the tourist internalized previously. In the pre-visit phase, the image is a set of expectations and perceptions a prospective traveller has about a destination [56]. There are often discrepancies between projected and perceived images. These can be grouped under two concepts [19]: discordance in the representations, when promoters distort reality to suit their interests that may not be coincident, and incongruity in the image when the projected image does not match the current perception of 
tourists. The contrast between positive image and negative reality often leads to disappointment or anger upon arrival, and false images restrict the learning potential of travel, one of its most valuable and enduring foundations [73]. The greater the difference between image and reality, that is, between expectation and experience, the more likely it is that tourists will be dissatisfied [74]. For example, when the image perceived in advance is positive and the reality perceived in situ is negative, there is a negative incongruity causing a great dislike [9].

- Place sustainability. Destination competitiveness is illusory without sustainability. From this perspective, the expression 'sustainable competitiveness' is tautological [1]. At the same time, one of the most influential researches in the scientific literature on tourism [56] stated: "Interestingly, the sustainability of local resources becomes one of the most important elements of destination image, as a growing section of the market is not prepared to tolerate over-developed tourism destinations and diverts to more environmentally advanced regions" (p. 101). From another perspective, tourists' perception affects brand image sustainability [75].

- Place identity and authenticity. Identity and authenticity are part of the projected image [70], but can also directly influence the experience through existential authenticity (oriented activity or experienced authenticity) [76]. These authors demonstrated the relationship between image, authenticity, identity, and place attachment.

- Satisfaction and loyalty. Perceived image through experience is a forerunner of tourist satisfaction and loyalty. At the same time, satisfaction is also an antecedent of loyalty. In tourism, loyalty is measured by intentions of future behaviour, specifically by the tourist's predisposition (attitude) to return to the place or recommend it both through WoM and eWoM. Satisfaction and loyalty have their negative side when they become dissatisfaction and disloyalty. Many authors have demonstrated these relationships. For example, a meta-analysis of 66 independent studies revealed that the impact of image on tourist loyalty is significant [13]. Tourism image is a direct antecedent of satisfaction and loyalty [65]; image directly influences satisfaction, and this has a direct and positive impact on loyalty to the destination [77]. Affective image is the main antecedent of loyalty [78]. Last, overall image (cognitive and affective images) indirectly influences tourists' behavioural intentions mediated by their satisfaction [79], which is positively affected by overall image, as are their intentions to recommend the destination [80]. In addition, satisfaction and loyalty are placed on the path that goes from the tourist to the agents, because overall satisfaction positively affects image and loyalty in all models [5].

\subsection{Image Components}

Image must be thought of as the overall cognitive, affective and evaluative structure of the behaviour unit, or its internal view of itself and its universe [64]. In this line, to analyse the image of a city or tourist destination, the doctrine has mostly used the tripartite cognitive-affective-conative model $[18,81-84]$ inherited from the field of psychology.

Table 1 compares the dominant model of image analysis [84] with another parallel [66] that adds spatial and evaluative dimensions. Both have in common the division of the interaction between the person and the environment in three areas: to have knowledge of something, to feel something about it and, therefore, to do something about it. They also agree in considering three distinct but hierarchically interrelated aspects. In parallel, the first two lead to the overall or composite image. An overall place image is formed because of both cognitive and affective evaluations of that place [17]. A composite place image is subjectively shaped by an interlaced system of both designative and appraisive perceptions [85].

The designative aspect refers to the physical characteristics of the resource such as shape, size, colour, texture, layout, and other details, and the mental map that concerns basic properties such as location, distance, orientation, and other spatial variations. City image is acquired and supported by an underlying network that represents the individual's movement field or activity space [66]. The mental image can also be relatively abstract; for example, the structure is identified as a "restaurant" 
or "the third building from the corner" [3]. The designative aspect may be less important by itself than the estimative, the meaning attached to-or evoked by-the physical form. Affective meaning is simply the emotional response to the environment that accompanies the perceptive and symbolic meanings. The evaluative dimension is a general opinion or judgement and preference that specifically involves the set of places to assess or classify [66]. The evaluative meaning simply refers to establishing a ranking between the best and the worst.

Table 1. Definition of components or aspects of image.

\begin{tabular}{|c|c|}
\hline Rapoport [84] (p. 28) & Pocock and Hudson [66] (p. 30) \\
\hline $\begin{array}{l}\text { Cognitive } \\
\text { Involves perceiving, knowing and thinking, the basic } \\
\text { processes whereby individuals knows their } \\
\text { environment. }\end{array}$ & $\begin{array}{l}\text { Designative } \\
\text { It is informational in nature, concerned with } \\
\text { description and classification-the basic "whatness" } \\
\text { and "whereness" of the image. }\end{array}$ \\
\hline $\begin{array}{l}\text { Involves feelings and emotions about the } \\
\text { environment, motivations, desires and values } \\
\text { (embodied in the images). }\end{array}$ & $\begin{array}{l}\text { Appraisive } \\
\text { It is one of appraisal or assessment. It incorporates } \\
\text { both evaluation and preference, the former including } \\
\text { some general or external standards, the latter } \\
\text { reflecting a more personal type of appraisal and } \\
\text { affection, the emotional response concerned with } \\
\text { feeling, value and meaning attached to the perceived. }\end{array}$ \\
\hline $\begin{array}{l}\text { Involves acting, doing, striving and thus having an } \\
\text { effect on the environment in response to } 1 \text { and } 2 \text {. }\end{array}$ & $\begin{array}{l}\text { Prescriptive } \\
\text { Relates to predictions and inference of both } \\
\text { descriptive and appraisive nature giving the image } \\
\text { depth, continuity, pattern, or meaning beyond that } \\
\text { justified by the experience of a particular scene alone. }\end{array}$ \\
\hline
\end{tabular}

The Pocock and Hudson model and similar ones were adopted in human geography by numerous authors to study human behaviour in relationships of people with the environment $[86,87]$. In an article on constructing the image of a country [88], the authors compared constructs of Table 1, in terms of country image, from a semantic dimension (meaning): Cognitive component $=$ designative meaning, affective component = appraisive meaning, and conative component = prescriptive meaning, and equating them with the attitude toward the product, from a pragmatic dimension (purpose).

\subsection{Proposed Model to Analyse the Image}

Figure 2 shows an adaptation of Pocock and Hudson's model (Table 1), with the addition of facilities and temporal dimension to the designative aspect, and the subdivision of the prescriptive aspect in behavioural and attitudinal responses.

- Facilities. Next to the structure and form that characterize physical image, concept has added facilities that cover the relatively abstract mental image [3] of a tourist resource. The visitor identifies a structure such as a museum, aquarium, spa, hotel, restaurant, or other services related to tourism. Not all authors have considered that services are attributes of the image. In a review of 25 articles on TDI [89], among the attributes commonly used in these studies, only $56 \%$ considered accommodation, $60 \%$ gastronomy, and $32 \%$ transportation. However, in one of the most influential papers in the scientific literature on TDI [90], infrastructure and activities (hotels, restaurants, bars, transport, excursions, etc.) are considered as determining dimensions or attributes of the perceived destination image. As has been shown, for example, the positive influence of the gastronomic experiences impacts the destination image and loyalty [91,92].

- Temporal dimension. The image is built and changes over time [93-95]. For example, a Mediterranean seafront does not have the same image in summer as it does in winter; similarly, the image of Japan is different in the season of flowering cherry trees compared to the rest of the year. 
- Prescriptive response. The prescriptive response has been specified, dividing it into behavioural and attitudinal to analyse the tourist's actions and loyalty (see Figure 1).

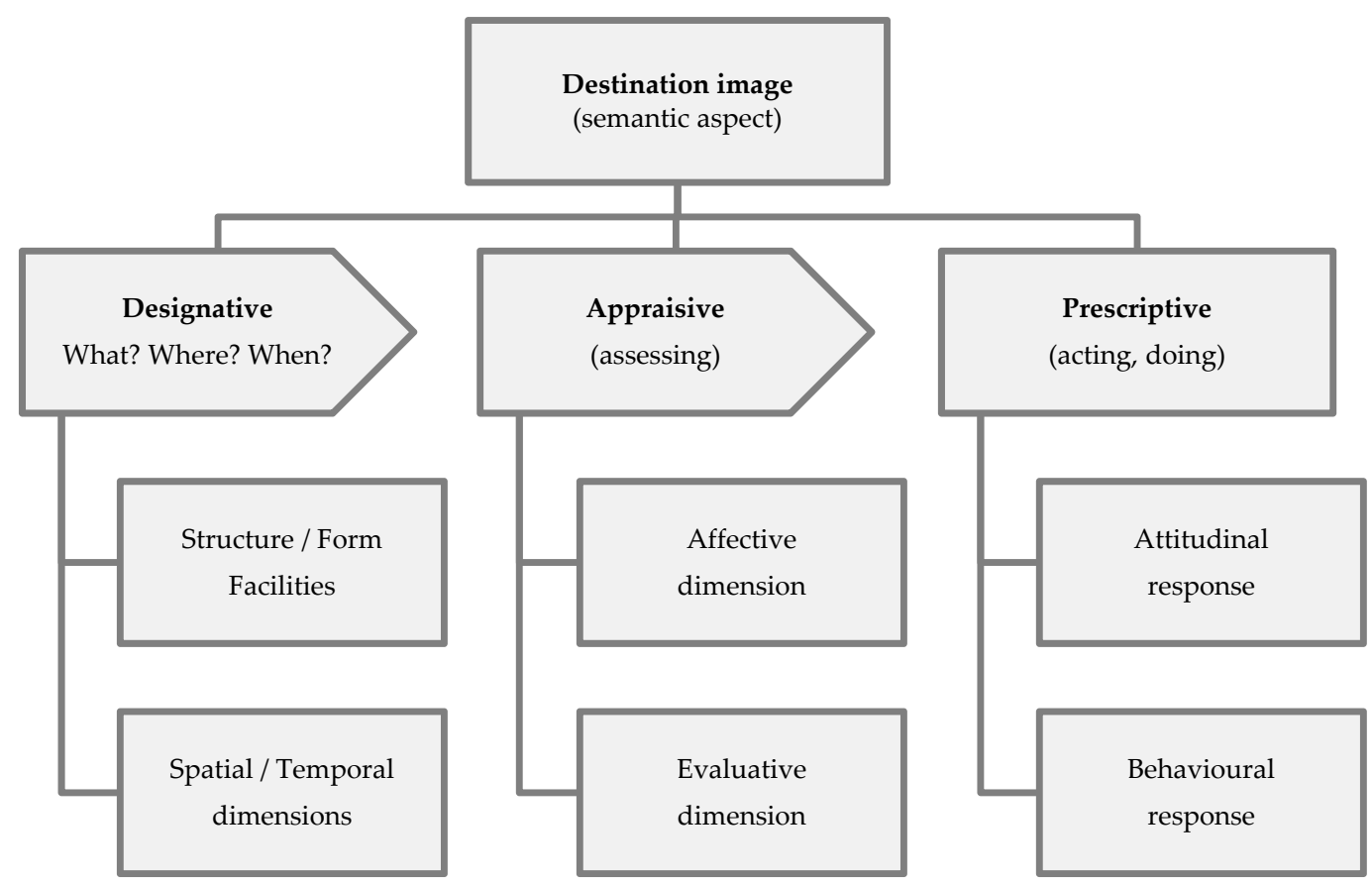

Figure 2. Destination image components, adapted from other authors [66].

\subsection{Use of Big Data Analytics in Hospitality and Tourism Research}

In a systematic review of literature from the Web of Science and Scopus published between 2000 and 2016, the authors selected 96 articles on big data and tourism, only 17 of which appeared in journals addressing hospitality or tourism [42]. In a similar review of literature from the Web of Science, ScienceDirect, SAGE Journals Online, Emerald Insight, Wiley Online Library and Springer published between 2007 and 2016, the authors examined 144 journal papers and 21 conference papers [41]. In a more recent literature review of work in Scopus published between 1990 and 2017, the authors selected 109 papers for descriptive as well as content analyses [40].

Among research using OTRs as a data source, two systematic literature reviews merit attention; one involved examining 65 papers published between 2000 and 2015 in seven major journals addressing tourism and hospitality [32], whereas the other involved examining 55 papers published between 2008 and 2017 and collected from six popular online databases as well as Google Scholar [33]. Table 2 summarises the research domains of both studies.

Table 2. Industry domains of online reviews of work addressing hospitality and tourism.

\begin{tabular}{ccccccc}
\hline Research Domain & $\begin{array}{c}\text { Number } \\
\text { (Kwok et al. [32]) }\end{array}$ & Percentage & $\begin{array}{c}\text { Number } \\
\text { (Hlee et al. [33]) }\end{array}$ & Percentage & N & Average \\
\hline Accommodations & 47 & 72.3 & 35 & 63.6 & 82 & $68.3 \%$ \\
$\begin{array}{c}\text { Restaurants } \\
\begin{array}{c}\text { Destinations and } \\
\text { tourism products }\end{array}\end{array}$ & 8 & 12.3 & 8 & 14.5 & 16 & $13.3 \%$ \\
\hline
\end{tabular}

Other recent studies that have used massive TGC as a data source have been based on reviews of hotels $[96,97]$ or restaurants $[98,99]$. A study focused on exploring similarities between attractions through 1,695,333 OTRs that highlighted Athens, Cairo and Rome in the category of ancient ruins deserves special attention [100]. As subsequent research has shown, people who use reviews of various 
tourism products have particular objectives, including opinion mining [101], especially for information about tourist satisfaction [102] and affective image [21]. Recent research based on 25,220 TripAdvisor reviews on things to do in an Italian province [103] is not focused on TDI, but it measures visitor satisfaction through its evaluation that uses between one and five bubbles and implements a content analysis using the commercial application Leximancer.

Among research on TDIs stemming from TGC, the results of which can be compared with those of the study presented here, four studies warrant mention. The first involved collecting and analysing 18,884 travel blogs and OTRs on VirtualTourist and TripAdvisor of the Basilica of La Sagrada Familia in Barcelona [104]; the second did the same with 132,502 travel blogs and OTRs on TravelBlog, VirtualTourist and TripAdvisor addressing Catalonia in general [105]; the third did that with 387,414 OTRs about "Things to Do" in Île de France on TripAdvisor [71]; and the fourth did it with 330,000 OTRs on TripAdvisor regarding Catalan territorial brands [106].

\subsection{Online Travel Reviews as a Big Data Source to Analyse the Image}

The schema of Figure 2, derived from a theoretical model conceived over 40 years ago [66], is useful for analysing the image perceived by visitors in the time of big data, TGC and social media. The adaptation can be explained by a simple example: A visitor walks through a park and sees a bank with certain characteristics in a particular environment (designative aspect). She/he thinks the bank seems comfortable, and the environment is pleasant (affective dimension). She/he sits on it and writes an online review about the place (behavioural response). She/he rates the place with a high score (evaluative dimension) and recommends the park and the bank (attitudinal response). Moreover, the paratextual elements of the OTR allow situating the experience in space and time (designative aspect).

In addition to the spontaneity of the story, opinion and assessment, OTRs have advantages over information sources based on surveys. For example, to elucidate the prescriptive aspect [13], the respondent had to be asked whether she/he intended to visit the attraction or area (behavioural response), or was asked if she/he thought back to it and recommended it (attitudinal response) to measure loyalty. With the TGC, we know directly what the visitor's behaviour and attitude has been. You can even know if the author had previously visited the area through the paratextual elements of previous OTRs.

The content of OTR can be considered semi-structured information because it houses structured data, but text written by the reviewer does not have a rigid structure that allows a quantitative analysis directly. The web page hosting a review contains three sources of useful data for analysing the image according to the model proposed in Figure 2: textual body of the review, hypertext mark-up language (HTML) metadata, and paratextual elements.

- Textual body. It is the most important part of the OTR. The reviewer recounts his/her experience and gives his/her opinion about the place she/he visited or the tourist resource she/he used. The writing does not contain structured information, except the structure derived from the syntactic grammar rules.

- HTML metadata [71]. Metadata from the web page are intended for reading by Internet browsers and search engines. They give varied information, such as coding and language of the page, but most interesting are those that give information directly related to the OTR, such as title, description, keywords, etc.

- Paratextual elements [107]. The term paratext [108] refers to a set of productions (title, preface, author's name, artworks, etc.) that accompany the text of a literary work. This French literary theorist divided the paratext in peritext and epitext according to the distance of the paratextual elements in relation to the location of the text itself. These productions may be the responsibility of the author, editor/publisher or both. Applying the theory to the case of OTRs, these elements are generated by the web server based on information provided by reviewers and advertisers who market their products or services on the web. Therefore, the title of the OTR, language, date, geographic location, topic or type of resource, the profile of the reviewer with the number of 
reviews, cities visited, etc., would be peritext. The epitext (related OTRs, contextual advertising, etc.) can be used to follow the path of its links but is not used directly in the analysis of the image.

After seeing the theoretical basis, a case study based on a prominent tourist destination and a popular website dedicated to the promotion and commercialisation of trips is then exposed to empirically demonstrate the usefulness of OTRs as a source of data to analyse the tourist image.

\section{Materials and Methods}

The proposed methodological framework (Figure 3) is an extension and update of previous research [71] to define and obtain the necessary metrics that allow measuring the image from the proposed theoretical framework (Figure 2). The previous framework was limited to analysing data from OTRs of attractions displayed among results on search engines; however, such information allowed measuring only the cognitive and affective components of TDIs via HTML metadata. By contrast, the current version also allowed analysing the conative component of TDIs in light of all information in OTRs, as well as to include data sources about other tourist resources such as hotels and restaurants.

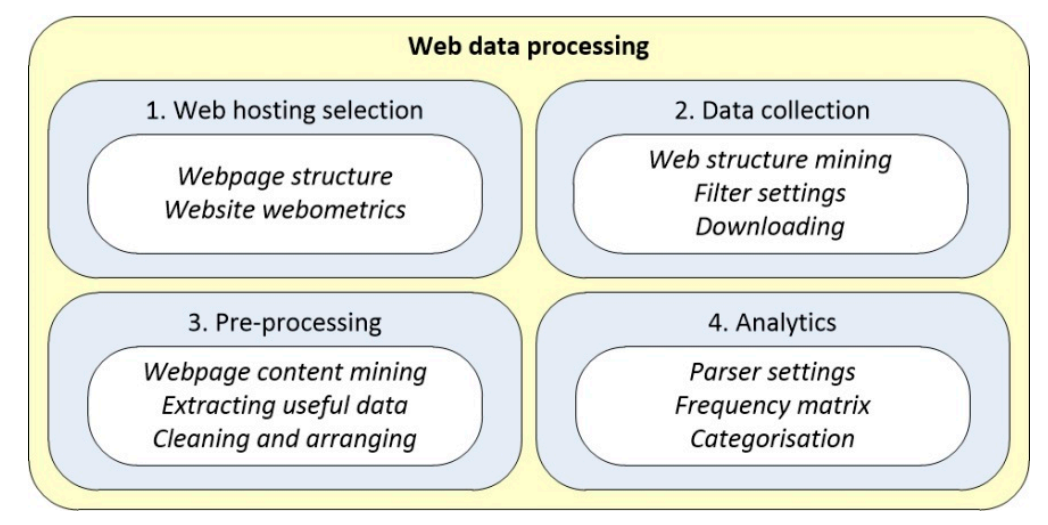

Figure 3. Methodological framework.

\subsection{Case Study: Attica}

Attica is a historical region of Greece that encompasses the entire metropolitan area of Athens. It is a leading tourist destination with 6.7 million nights spent at tourist accommodation establishments by foreign tourists in 2017 [109]. Its most important tourist resource is the Acropolis, an ancient Greek monumental complex declared a World Heritage Site [59]. Attica is classified by the European Union, as a NUTS-2 region (nomenclature of territorial units for statistics), with the code EL30. To study the spatial dimension of the image, the region has been divided into seven subregions: North Athens (NA), Athens (At), South Athens (SA), East Attica (EA), West Attica (WA), Piraeus (Pi), and islands (Is: mainly Saronic Gulf islands).

\subsection{Webhost Selection and Data Collection}

Based on the webometrics of popularity, visibility and size [110], TripAdvisor is selected as the most suitable website for the case study. TripAdvisor [111] hosts almost a million reviews and opinions about the Greek region of Attica. Once the filters are established, OTRs of three sections (Things to Do, Restaurants, and Hotels and Places to Stay) are downloaded through a web copy programme.

\subsection{Pre-Processing}

The relevant information for the case study can be extracted from the OTR webpages, through a search utility that supports regular language expressions (search patterns). The main data sources are the textual and paratextual elements, as well as some HTML metadata contained in the webpage (see Section 2.4). The extracted information must be debugged and arranged for further processing. 
The most-representative language of the OTRs posted by foreign visitors is English. To delimit the temporal dimension, OTRs written in English between 2013 and 2018 were selected. As an exploratory study and to facilitate comparison of the metrics between the three segments, a random sample of 100,000 OTRs in each section was extracted (Tables A1-A3, Appendix A). The representativeness of the samples was different in each case (75\% attractions, $95 \%$ hotels, and $60 \%$ restaurants). Figure 4 shows the temporal distribution of the sample.

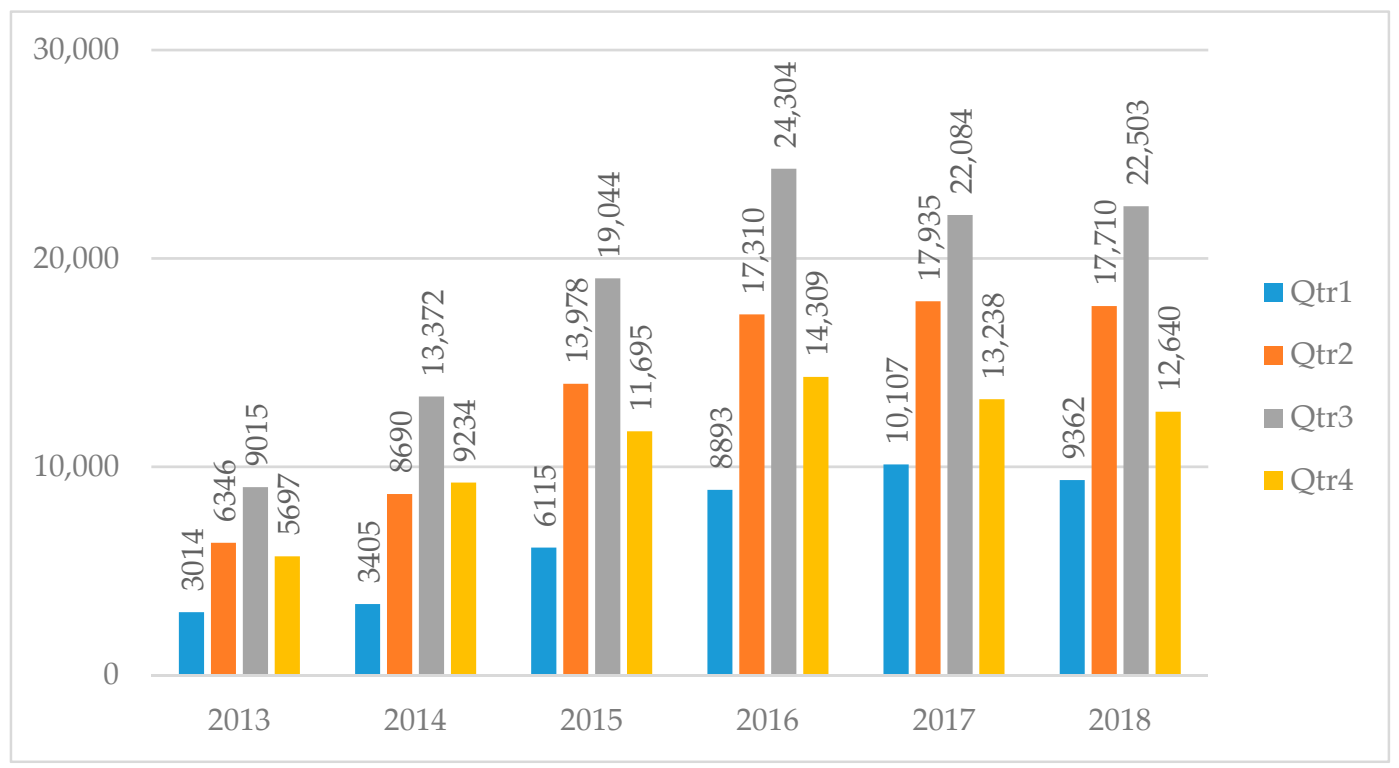

Figure 4. Temporal distribution of 300,000 TripAdvisor online travel reviews on Attica.

\subsection{Analytics}

Content analysis is a research method for making valid inferences from meaningful matter that contains useful, diverse and unstructured information, through mapping symbolic data into a data matrix suitable for statistical analysis [112]. The most-used techniques are based on a word-frequency count because the most-mentioned words reflect greater interest [113].

Figure 5 shows the algorithm used to generate the word-frequency table based on the text extracted from the OTR webpages. The list of composite words contains groups of two or more words that have a different meaning from words alone (e.g., Temple of Olympian Zeus, must-see, not a must). The blacklist contains words that are not significant in the case study (e.g., determiners, pronouns, adverbs, prepositions, conjunctions). In the case of overlap between words, the algorithm gives priority to composite words. For example, "not so nice" has preference over "not" and "so" (stop words) and over "nice" (keyword). If the overlap is between composite words, the algorithm gives preference by list order. For example, "not do it" has preference over "do it" because it is earlier in the list.

For quantitative and thematic content analysis, categories based on word-frequency tables are constructed. The categories, which must be mutually exclusive and exhaustive, include words or groups of words with similar meaning or connotation [113] excluding polysemous words. To avoid a process of lemmatisation, inflected forms of keywords (e.g., amaze, amazing, amazingly) are included within the categories. The main categories and metrics related to the model in Figure 2 are detailed below.

- Structure/form and facilities. Each touristic resource of TripAdvisor has a code and name. From the outset, TripAdvisor hosts in different sections OTRs about attractions, hotels and restaurants. The attractions are classified according to their type (e.g., monuments and statues, museums), activity (e.g., sightseeing tours, outdoor activities), or service (e.g., transportation, taxis and shuttles). Hotels have a rating of one to five stars. Star ratings indicate the general level of features and amenities to expect. They are provided to TripAdvisor by third-party partners such as Expedia 
and Giata. Restaurants include bars, cafes and pubs that serve food and are classified by region (e.g., Mediterranean, Asian), country (e.g., Greek, Italian), type of food (e.g., steakhouse, seafood) and other considerations (e.g., fast food, healthy). Metrics derived from the above data provide valuable information about the designative component of the image. Another important metric is popularity, which measures the number of OTRs for each resource sent during the period studied.

- Spatial and temporal dimensions. The resources of TripAdvisor have the name, geographic code and country of the tourist destination (e.g., Spata, Hydra) where they are located. In some cases, they also have the region (e.g., East Attica, Piraeus). With this information, the subregions of Section 3.1 have been delimited. The temporal dimension depends on the date of the experience (perceived image) and the date of publication of the OTR (projected image). Due to the great proliferation of mobile devices, there is little difference between both dates. The analysis has been made based on the publication date because from this moment, the OTR is available online for any user.

- Evaluative dimension. All TripAdvisor OTRs on tourism resources have a score of between one and five bubbles: Excellent ( 5 bubbles), Good ( 4 bubbles), Average ( 3 bubbles), Poor ( 2 bubbles), and Terrible ( 1 bubble). The proposed metrics distinguish between the number of positive and negative evaluations: positive scores $($ score +$)=5$ bubbles +4 bubbles, and negative scores (score-) $=2$ bubbles +1 bubble Another metric (average score) results from calculating the weighted average after converting the bubble ratings to a scale of zero to ten: 5 bubbles $=10 ; 4$ bubbles $=7.5 ; 3$ bubbles $=5 ; 2$ bubbles $=2.5$; and 1 bubble $=0$.

- Affective dimension. Sentiment analysis tries to deduce from the content of a message the positive or negative polarity of the feelings and moods of the author from, mainly, adjectives that she/he has used. Intensity is difficult to quantify (e.g., amazing, simply amazing, pretty amazing, absolutely amazing). In this case, of study, the affective dimension has been quantified by the number of adjectives and other words that indicate positive or negative feelings or moods. From the table of frequency of words and a lexicon with a list of positive words (e.g., beautiful, happy) and negative words (e.g., crowded, disappointed), two metrics are proposed: positive feelings (feelings+) and negative feelings (feelings-). Both are calculated by the percentage of positive or negative words in relation to the total number of words (including stop words). The affective dimension can also be classified by topics, building categories of keywords with positive or negative polarities. For example, OTRs of visits to popular attractions often include complaints about crowds, queues and waiting times. In such a case, a category for crowdedness can be constructed to measure the intensity of the sustainability problem. Other categories with negative connotations could be riskiness and dirtiness.

- Attitudinal and behavioural responses. In studies of tourist loyalty, attitudinal loyalty refers to tourists' intention to recommend place or tourist resource, and behavioural loyalty focuses on intention to visit or revisit the place [13]. By analysing OTRs content, it is not necessary to ascertain tourists' intention because you can directly know their behaviour and attitude. Applying the same method of the previous paragraph and a lexicon of positive recommendations (e.g., must-see, cannot miss, recommend) and negative recommendations and warnings (e.g., avoid, do not stay here, would not recommend), two metrics are proposed: positive recommendations (recommendations + ) and negative recommendations and warnings (recommendations-).

The sentiment analysis algorithm goes through the keyword-frequency table and classifies the following locutions from the example OTR (Box 1): lovely (positive feeling); be aware of (warning/negative recommendation); 2 pickpockets (negative feelings); suffering and shame (moods/negative feelings); and worth a visit (positive recommendation). The algorithm classifies the keywords based on the available categories. 


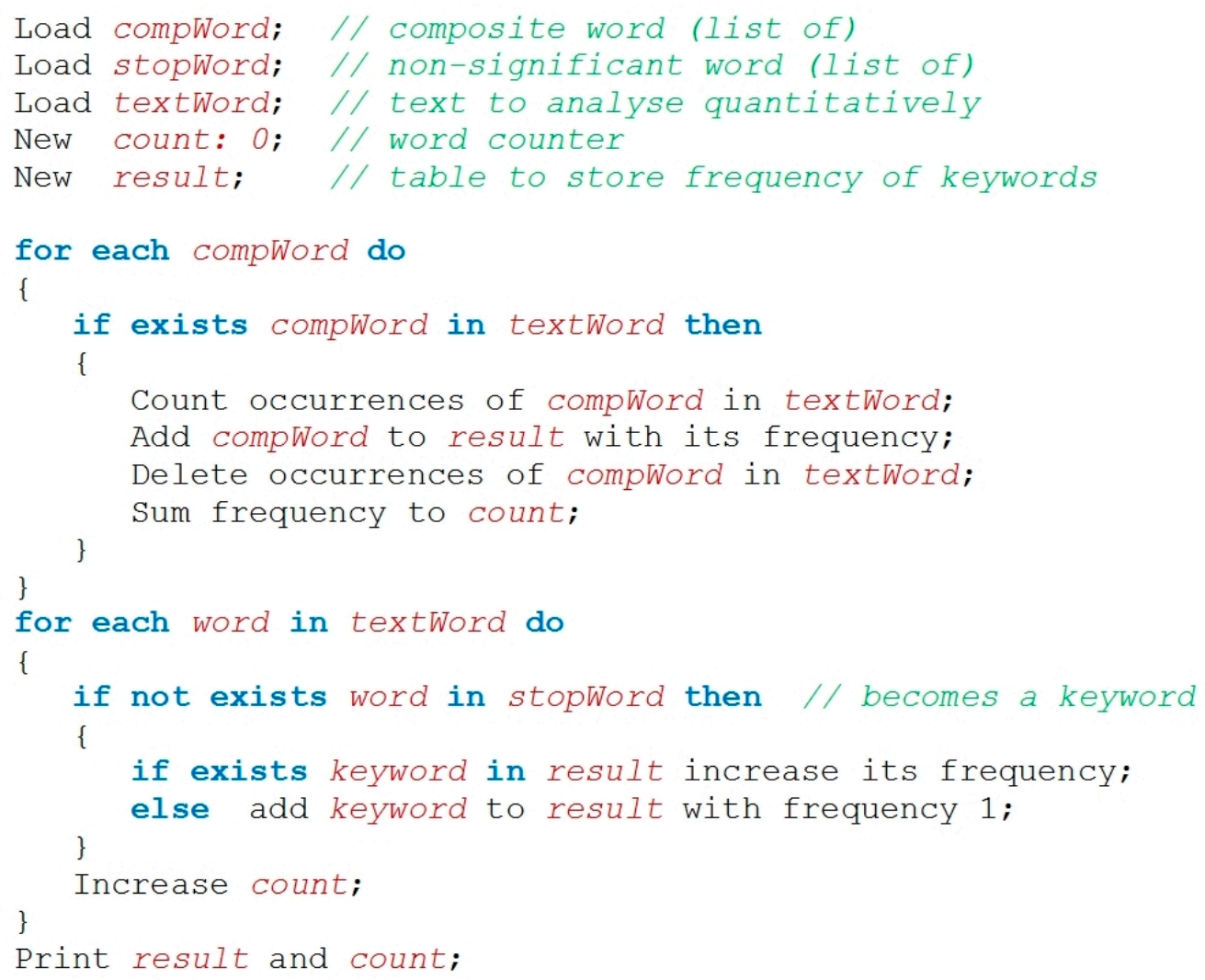

Figure 5. Algorithm to generate the word-frequency table, derived from Marine-Roig [71].

Box 1. TripAdvisor online travel review example (without personal identification data).

Reviewer: A TripAdvisor Member; from: New York City, New York; score: 4; date: 2013-07-24; attraction: Plaka; location: Athens; language: English; title: A lovely place to potter, unwind, dine and shop; text: The title says it all, but two things to be aware of-pickpockets and graffiti. Apparently, Athens is suffering with Eastern European gangs of pickpockets, like London so keep your hand on your wallet. And there is a lot of graffiti which is quick a shame. None the less worth a visit.

\section{Results}

The first results of the spatial and temporal dimensions of the image arise directly from the extraction and arrangement of the data (Section 3.3). The metropolis (Athens) accumulates $90 \%$ of the OTRs on attractions (Table A1), 72\% on hotels (Table A2) and 69\% on restaurants (Table A3). The Islands are in second position in relation to the OTRs on hotels and restaurants. In all cases (Figure 4), the third quarter stands out due to the high number of OTRs. In terms of trends, the number of OTRs increased between 2013 and 2016 and decreased in the following years in the case of attractions (Table A1) and hotels (Table A2). On the contrary, OTRs on restaurants continue to grow during 2017 and 2018 (Table A3).

Table A10 shows the 12 most frequent keywords in the text of the OTRs (31.8 million words). Highlights Athens (69,297 occurrences) in attractions, hotel (190,608 occurrences) in hotels, and food (92,552 occurrences) in restaurants. In the three columns, there are keywords related to positive feelings (e.g., good, great). The crowdedness-related keywords crowd/s/ed/ing (7386), overcrowd/ed/ing (186), busy (2623), line/s (3392), queue/s (1139), wait/ed/ing (5243), and await/ing (72), together with ticket/s/ing (8563), and the dirtiness-related keywords abandoned (79), derelict (11), dirty (293), garbage (53), junk (101), rubbish (51), ruined (230), and trash (75), together with graffiti (420), that may indicate sustainability problems, appear in the attractions column. The riskiness-related keywords 
crime/inal/inally (103), danger/ous (122), pick pocket pickpocket/s (422), robbed robbery (66), steal stole/n (416), and thief/ves (97) also appear in the attractions column.

\subsection{Designative Aspect}

Table A4 shows the ten most-popular attractions and activities. First, there is the Acropolis [59] and its museum with twice as many reviews as the third classified. Among these top ten, there are three companies dedicated to commercialising transportation and tours. Tours are the most frequent type of activity (Table 3), although it should be remembered that an attraction or activity can be classified according to different concepts (e.g., private tour and transportation companies in the ranks of sixth, ninth and tenth in Table A4).

Table 3. Most frequent types of attractions and activities (Table A4, column Type).

\begin{tabular}{cccccc}
\hline Type & $\mathbf{\%}$ & Type & $\mathbf{\%}$ & Type & $\mathbf{\%}$ \\
\hline Tours & 24.65 & Shopping & 4.13 & Private Tours & 2.80 \\
Museums & 6.85 & Bars \& Clubs & 3.78 & Gift \& Speciality Shops & 2.56 \\
Sights \& Landmarks & 6.05 & Transportation & 3.73 & Boat Tours \& Water Sports & 2.50 \\
Outdoor Activities & 5.68 & Fun \& Games & 2.98 & City Tours & 1.92 \\
Nightlife & 4.53 & Taxis \& Shuttles & 2.90 & Spas \& Wellness & 1.71 \\
Bar & 4.53 & Nature \& Parks & 2.88 & Beaches & 1.68 \\
\hline
\end{tabular}

Table A6 shows the ten most-popular hotels. Unlike most popular attractions and restaurants concentrated in Athens, a hotel is located outside of Athens and has the highest number of OTRs. All hotels have four or five TripAdvisor stars, except one that has three stars. Table 4 provides information about the distribution of hotels by star rating (e.g., hotels in the ranks of sixth, seventh and eighth in Table A6). Almost one in three hotels has four stars, followed by three-star (27.09\%) and two-star $(26.25 \%)$ hotels.

Table 4. Frequency (\%) of hotels by star rating (Table A6, column Class).

\begin{tabular}{ccccccccc}
\hline 5 Stars & 4.5 Stars & 4 Stars & 3.5 Stars & 3 Stars & 2.5 Stars & 2 Stars & 1.5 Star & 1 Star \\
\hline 9.99 & 0.17 & 30.74 & 4.57 & 22.52 & 1.19 & 25.06 & 0.17 & 5.59 \\
\hline
\end{tabular}

Table A8 shows the ten most-popular restaurants. The first two offer local cuisine (Greek-Mediterranean). Table 5 shows that most restaurants specialise in local cuisine. It must be considered that a restaurant can be classified by different concepts (e.g., restaurants in the ranks of first and second in Table A8).

Table 5. Most frequent specialisation of establishments serving food (Table A8, column Type).

\begin{tabular}{cccccccc}
\hline Region & $\mathbf{\%}$ & Country & $\mathbf{\%}$ & Structure & $\mathbf{\%}$ & Kind of Food & $\mathbf{\%}$ \\
\hline Mediterranean & 17.66 & Greek & 25.22 & Cafe & 7.10 & Seafood & 4.79 \\
European & 3.95 & Italian & 3.57 & Bar & 6.12 & Vegetarian & 4.62 \\
American & 1.95 & Japanese & 0.71 & Pizza & 1.90 & Steakhouse & 2.68 \\
Asian & 1.01 & Chinese & 0.59 & Pub & 1.77 & Fast food & 2.37 \\
\hline
\end{tabular}

\subsection{Appraisive and Prescriptive Aspects}

Table A5 shows the scores of the ten most-popular attractions or activities. In general, all the scores are very high, but the best scores are for companies dedicated to organising tours. Table A7 shows the scores of the ten most-popular hotels. Only one hotel exceeds the weighted average score of nine points. Table A9 shows the scores of the ten most-popular restaurants. Most of these restaurants have an excellent rating. 
Table 6 shows a summary of the results of the sentiment analysis, according to the metrics defined in Section 3.4 (a real-world and comprehensive example related to appraisive and prescriptive stages can be found at the end of Section 3). The evaluative and affective dimensions of the appraisal aspect are both necessary because they can have different values. For example, attractions in Table 6 have the best weighted average of all scores (evaluative dimension) and the highest percentage of keywords related to recommendations and warnings (attitudinal response) but the lowest percentage of keywords related to feelings and moods (affective dimension).

Table 6. Summary of sentiment analysis (percentage) according to the metrics defined in Section 3.4.

\begin{tabular}{cccccccc}
\hline Resource & Feelings & Feelings - & Recommendation+ & Recommendation- & Score+ & Score- & Average Score \\
\hline Attractions & 3.9687 & 0.4254 & 0.5264 & 0.0709 & 92.1160 & 2.4680 & 87.1465 \\
Hotels & 4.6561 & 0.5883 & 0.2410 & 0.0421 & 80.4760 & 7.5390 & 75.6139 \\
Restaurants & 5.4675 & 0.6267 & 0.4350 & 0.0457 & 85.0030 & 7.3230 & 81.9132 \\
\hline
\end{tabular}

\subsection{Discussion}

The seasonality problem shown in Figure 4 is present in other countries of the Mediterranean coast with an increased tourist influx during the summer [105]. Regarding sustainability, the frequency of keywords (Table A10) related to crowdedness in visits to the attractions is much lower than that of other attractions such as the Louvre Museum in Paris [71] or the Basilica of the Sagrada Familia in Barcelona [104]. In all sections (attractions, hotels and restaurants), the spatial dimension shows a high concentration of OTRs in the metropolis and very little in the West Attica subregion. Among the ten most-popular resources, only one hotel is outside Athens in the East Attica subregion. Most restaurants (Table 5) specialise in local cuisine (Greek-Mediterranean). Remarkably, restaurants classified as fast food $(2.37 \%)$ outweigh those classified as healthy $(0.48 \%)$. In terms of trends, it is noteworthy that the number of restaurants' OTRs is growing, while it is decreasing in the case of attractions and hotels. Table 6 shows a certain contrast between the evaluative and affective dimensions of the image [71]. As in other cities [106], companies dedicated to organising tours get better scores than attractions declared World Heritage Sites. According to a recent study [100], Attica stands out for its attractions classified as ancient ruins. Overall, the image of Attica is very positive (Table 6), coinciding with a previous study on the TDI of Athens during the recession years [21].

\section{Concluding Remarks}

The proposed framework allows deducing TDIs from big data extracted from OTRs on sites and tourist resources at destinations. Regarding the case study, the image of Attica has been highly positive, especially in relation to restaurants and attractions. In the random sample of 300,000 OTRs, over 250,000 reviews are for the city of Athens. The two most reviewed restaurants, with a score higher than nine, offer Greek cuisine. Similarly, the Acropolis [59], its museum and the Parthenon stand out in the case of attractions. The hotels have a high level of features and amenities; more than $40 \%$ have a rating between four and five stars. In relation to visitors' loyalty, the positive recommendations far outweigh the negative ones. Several private tour and transportation companies are very popular and well valued by reviewers.

\subsection{Theoretical Implications}

The scientific study of the image of cities and, later, of tourist destinations has continued for more than half a century. After the seminal work of Lynch [3], influential authors in the field have included Hunt [6], Crompton [15], Chon [9], Gartner [18] and Baloglu and McCleary [17]. However, none of those researchers from the last century could have imagined the incredible increase of UGC spread via social media. The dramatic expansion of TGC has induced a paradigm shift in research on travel, tourism and hospitality, and consequently, surveys and in-depth interviews are no longer essential to gathering information on the opinions of visitors about tourist destinations, because it 
can be obtained for free from social media networks. This TGC constitutes a new and unsolicited organic image-formation agent in Gartner's model [18], with a penetration in the market, through eWoM, higher than that of the induced and autonomous sources.

Most image studies took into consideration the sights for travellers to visit as the main attributes of the destination. Now, as several surveys have shown [30,45], users consult TGC online mainly about hotels and restaurants at the destination. Without undermining the strong influence of tangible heritage on cities' images, both the accommodation sector and the gastronomic image contribute to TDI formation. In this regard, the diagrams in Figures 1 and 2 represent an all-encompassing model to measure TDIs and, indirectly, several aspects related to the sustainability of the destination, as well as the satisfaction and loyalty of visitors. In short, the study presented here involved an attempt to offer an initial integrated framework for analytics on TDIs from a massive amount of TGC, based on the visitor's experience on sightseeing, lodging and dining in the tourist destination, that other researchers can scrutinise, discuss or develop.

Moreover, Figure 1 shows a series of personal and social variables that affect the image perceived by tourists. Big data neutralises this subjective bias because it allows adding the opinions of hundreds of thousands of people, from different countries and cultures, on many places and tourist resources, which collectively constitutes the image as a whole.

\subsection{Managerial Implications}

Until now, existing studies on OTRs focused on destinations, accommodations, restaurants, or attractions separately. Only $14.5 \%$ of the investigations were focused on overall tourism products [33]. In this sense, the proposed metrics have application for OTRs on any tourist place, product or resource. These metrics allow measuring and comparing the image perceived by tourists on two or more resources or groups of tourist resources, places, cities, countries, and regions in certain years or seasons of the year. Based on the paratextual elements, OTRs can be segmented by languages and tourists' nationality [106].

The information obtained with the proposed metrics can be useful for DMOs, because it is based on the opinions and evaluations freely expressed by visitors, which allows deducing their preferences, needs and degrees of satisfaction. The findings can be complemented with results from other sources of big data or with those of conventional approaches that rely on communication-based methods [114]. Knowledge of TDIs perceived by visitors can inform ways to enhance the sustainability of tourist destinations by appropriately distributing available resources at those destinations. The proposed metrics are also useful for extracting business intelligence. For example, the managers of a hotel or a restaurant can compare their results with those of similar properties to gain insights; or they can compare the results before and after making renovations to an establishment. In addition, the crowdedness category can serve to evaluate the success of reforms or changes in the systems of ticket purchases and access to a popular museum, for example.

For policymakers in Attica, the results in the dirtiness and riskiness categories indicate that it would be beneficial to refurbish and clean the urban area of Athens, as well as to improve the area's safety for visitors, especially by controlling the behaviours of graffiti artists and pickpockets. Furthermore, amid the growing popularity of restaurants in the region, most of which offer Greek cuisine, it remains incomprehensible that restaurants classified as fast-food establishments have increased by fivefold compared to those classified as healthy restaurants. Since tourism is highly concentrated in the metropolis, it would be advisable to promote other areas with highly attractive natural resources for tourists, particularly by planning the sustainable tourism exploitation of paradisiacal islands that comprise the region.

\subsection{Limitations and Future Research}

A limitation of the study was that attractions and restaurants can be classified into several categories on TripAdvisor. In addition, it is virtually impossible to build mutually exclusive and exhaustive 
categories related to sentiments, crowdedness, dirtiness, riskiness, etc., but correct classification of keywords can be obtained in most cases. Moreover, although the samples were based on a function that generates random numbers of 15 decimals between zero and one, which makes it nearly impossible for repetitions to occur, their representativeness remains questionable. Although that method was performed to facilitate a superficial comparison of results, it also allowed working with all of the available information, while the proposed metrics facilitated the statistical exploitation of the data.

Although the TripAdvisor website has the highest number of OTRs, it would be interesting to contrast results from other online reviews platforms [114] such as Booking, Expedia, Yelp, Ctrip or Airbnb, especially in the accommodation sector.

Funding: The author is pleased to acknowledge the support of the Spanish Ministry of Economy, Industry and Competitiveness (Grant id.: TURCOLAB ECO2017-88984-R).

Conflicts of Interest: The author declares no conflict of interest.

\section{Appendix A}

Table A1. Spatial and temporal distribution of 100,000 TripAdvisor OTRs on Attractions.

\begin{tabular}{lcccccccc}
\hline Resource & Year & Athens & EA & WA & NA & SA & Piraeus & Islands \\
\hline \multirow{6}{*}{ Attractions } & 2013 & 6717 & 133 & 7 & 13 & 75 & 98 & 96 \\
& 2014 & 9447 & 274 & 7 & 20 & 166 & 199 & 292 \\
& 2015 & 15,191 & 547 & 19 & 37 & 281 & 300 & 463 \\
& 2016 & 19,843 & 714 & 29 & 155 & 416 & 448 & 667 \\
& 2017 & 19,654 & 644 & 23 & 143 & 414 & 436 & 602 \\
& 2018 & 19,113 & 804 & 29 & 118 & 293 & 394 & 679 \\
\hline
\end{tabular}

Table A2. Spatial and temporal distribution of 100,000 TripAdvisor OTRs on Hotels.

\begin{tabular}{ccccccccc}
\hline Resource & Year & Athens & EA & WA & NA & SA & Piraeus & Islands \\
\hline \multirow{6}{*}{ Hotels } & 2013 & 8258 & 1226 & 43 & 223 & 305 & 507 & 1244 \\
& 2014 & 11,019 & 1401 & 30 & 286 & 472 & 583 & 1485 \\
& 2015 & 13,372 & 1685 & 59 & 358 & 604 & 608 & 1669 \\
& 2016 & 14,327 & 2011 & 53 & 432 & 681 & 751 & 1988 \\
& 2017 & 13,427 & 1630 & 58 & 397 & 606 & 519 & 1563 \\
& 2018 & 11,750 & 1502 & 47 & 289 & 592 & 429 & 1511 \\
\hline
\end{tabular}

Table A3. Spatial and temporal distribution of 100,000 TripAdvisor OTRs on Restaurants.

\begin{tabular}{lcccccccc}
\hline Resource & Year & Athens & EA & WA & NA & SA & Piraeus & Islands \\
\hline \multirow{6}{*}{ Restaurants } & 2013 & 3722 & 220 & 5 & 297 & 294 & 103 & 486 \\
& 2014 & 6455 & 450 & 8 & 525 & 529 & 208 & 845 \\
& 2015 & 11,035 & 781 & 26 & 952 & 1000 & 458 & 1387 \\
& 2016 & 14,948 & 1423 & 51 & 1409 & 1623 & 626 & 2221 \\
& 2017 & 15,866 & 1568 & 76 & 1324 & 1594 & 669 & 2151 \\
& 2018 & 17,019 & 1718 & 81 & 1260 & 1633 & 685 & 2269 \\
\hline
\end{tabular}

Table A4. Top 10 Attractions and activities by number of TripAdvisor OTRs.

\begin{tabular}{|c|c|c|c|}
\hline Resource Name & Region & Count & Type \\
\hline Acropolis Museum & Athens & 13,258 & Museums, History Museums \\
\hline Acropolis & Athens & 12,082 & Sights and Landmarks, Historic Sites, Ancient Ruins \\
\hline Parthenon & Athens & 5285 & $\begin{array}{l}\text { Sights and Landmarks, Points of Interest and Landmarks, } \\
\text { Historic Sites, Architectural Buildings, Ancient Ruins }\end{array}$ \\
\hline
\end{tabular}


Table A4. Cont.

\begin{tabular}{|c|c|c|c|}
\hline Resource Name & Region & Count & Type \\
\hline Plaka & Athens & 5157 & Other, Sights and Landmarks, Neighbourhoods \\
\hline Archaeological Museum & Athens & 2540 & Museums, History Museums, Art Museums \\
\hline Welcome Pickups & Athens & 2310 & Transportation, Taxis and Shuttles \\
\hline Panathenaic Stadium & Athens & 2130 & Sights and Landmarks, Arenas and Stadiums \\
\hline Mount Lycabettus & Athens & 2016 & Sights and Landmarks, Lookouts \\
\hline Private Greece Tours & Athens & 1797 & $\begin{array}{c}\text { Tours, Sightseeing Tours, Day Trips, Multi-day Tours, } \\
\text { Private Tours, Archaeology Tours }\end{array}$ \\
\hline George's Taxi & Athens & 1778 & $\begin{array}{l}\text { Tours, Transportation, Multi-day Tours, Taxis and Shuttles, } \\
\text { City Tours, Sightseeing Tours, Private Tours }\end{array}$ \\
\hline
\end{tabular}

Table A5. Reviewer's scores for the top 10 Attractions and activities by number of TripAdvisor OTRs.

\begin{tabular}{ccccccccc}
\hline Resource Name & Region & Count & 5 Bubbles & 4 Bubbles & 3 Bubbles & 2 Bubbles & 1 Bubble & Score \\
\hline Acropolis Museum & Athens & 13,258 & 10,220 & 2335 & 560 & 110 & 33 \\
Acropolis & Athens & 12,082 & 9072 & 2291 & 569 & 96 & 54 \\
Parthenon & Athens & 5285 & 4089 & 942 & 205 & 35 & 14 \\
Plaka & Athens & 5157 & 3104 & 1562 & 410 & 64 & 17 \\
Archaeological Museum & Athens & 2540 & 1831 & 525 & 143 & 28 & 13 \\
Welcome Pickups & Athens & 2310 & 2144 & 69 & 18 & 13 & 6.28 \\
Panathenaic Stadium & Athens & 2130 & 1253 & 582 & 259 & 32 & 4 \\
Mount Lycabettus & Athens & 2016 & 1334 & 528 & 121 & 25 & 8.07 \\
Private Greece Tours & Athens & 1797 & 1752 & 39 & 3 & 1 & 8 \\
George's Taxi & Athens & 1778 & 1748 & 25 & 3 & & 2 \\
\hline
\end{tabular}

Table A6. Top 10 Hotels by number of TripAdvisor OTRs.

\begin{tabular}{cccc}
\hline Resource Name, Place & Region & Count & Class \\
\hline Sofitel Athens Airport, Spata & East Attica & 3042 & 5 stars \\
Hilton Athens, Athens & Athens & 2668 & 5 stars \\
Hotel Grande Bretagne, a Luxury Collection Hotel, Athens & Athens & 2513 & 5 stars \\
The Athens Gate Hotel, Athens & Athens & 2404 & 4 stars \\
Electra Palace Athens, Athens & Athens & 2272 & 5 stars \\
Plaka Hotel, Athens & Athens & 2072 & 3 stars \\
Royal Olympic, Athens & Athens & 2031 & 5 stars \\
Herodion Hotel, Athens & Athens & 1879 & 4 stars \\
St. George Lycabettus Lifestyle Hotel, Athens & Athens & 1782 & 5 stars \\
InterContinental Athenaeum, Athens & Athens & 1778 & 5 stars \\
\hline
\end{tabular}

Table A7. Reviewer's scores for the top 10 Hotels by number of TripAdvisor OTRs.

\begin{tabular}{|c|c|c|c|c|c|c|c|c|}
\hline Resource Name & Region & Count & 5 Bubbles & 4 Bubbles & 3 Bubbles & 2 Bubbles & 1 Bubble & Score \\
\hline Sofitel Athens Airport & EA & 3042 & 1577 & 941 & 344 & 111 & 69 & 8.16 \\
\hline Hilton Athens & Athens & 2668 & 1484 & 779 & 249 & 95 & 61 & 8.31 \\
\hline Hotel Grande Bretagne & Athens & 2513 & 1938 & 418 & 98 & 31 & 28 & 9.19 \\
\hline The Athens Gate Hotel & Athens & 2404 & 1414 & 811 & 135 & 30 & 14 & 8.72 \\
\hline Electra Palace Athens & Athens & 2272 & 1411 & 634 & 155 & 49 & 23 & 8.70 \\
\hline Plaka Hotel & Athens & 2072 & 1230 & 709 & 101 & 24 & 8 & 8.78 \\
\hline Royal Olympic & Athens & 2031 & 681 & 694 & 366 & 178 & 112 & 7.04 \\
\hline Herodion Hotel & Athens & 1879 & 1080 & 644 & 122 & 22 & 11 & 8.67 \\
\hline $\begin{array}{l}\text { St. George Lycabettus } \\
\text { Lifestyle Hotel }\end{array}$ & Athens & 1782 & 633 & 647 & 294 & 146 & 62 & 7.30 \\
\hline $\begin{array}{c}\text { InterContinental } \\
\text { Athenaeum }\end{array}$ & Athens & 1518 & 683 & 578 & 179 & 51 & 27 & 8.03 \\
\hline
\end{tabular}


Table A8. Top 10 Restaurants by number of TripAdvisor OTRs.

\begin{tabular}{cccc}
\hline Resource Name & Region & Count & Type \\
\hline Arcadia Restaurant & Athens & 1192 & Seafood, Mediterranean, Greek \\
Lithos & Athens & 1190 & Mediterranean, Greek, Vegetarian Friendly \\
O Thanasis & Athens & 1179 & Fast food, Mediterranean, Barbecue \\
Ta Karamanlidika tou Fani & Athens & 1167 & Middle Eastern, Mediterranean, Greek \\
Liondi Traditional Greek Restaurant & Athens & 1096 & Mediterranean, Greek, Vegetarian Friendly \\
Oineas Restaurant & Athens & 888 & Mediterranean, European, Greek \\
Avocado & Athens & 807 & Mediterranean, European, Greek \\
Gods Restaurant & Athens & 738 & Mediterranean, Greek, Contemporary \\
Smile Café Restaurant & Athens & 719 & Mediterranean, Greek, Vegetarian Friendly \\
Oroscopo & Athens & 687 & Italian, European, Greek \\
\hline
\end{tabular}

Table A9. Reviewer's scores for the top 10 Restaurants by number of TripAdvisor OTRs.

\begin{tabular}{ccccccccc}
\hline Resource Name & Region & Count & 5 Bubbles & 4 Bubbles & 3 Bubbles & 2 Bubbles & 1 Bubble & Score \\
\hline Arcadia Restaurant & Athens & 1192 & 916 & 205 & 44 & 15 & 12 & 9.19 \\
Lithos & Athens & 1190 & 944 & 189 & 39 & 12 & 6 & 9.31 \\
O Thanasis & Athens & 1179 & 606 & 376 & 119 & 49 & 29 & 8.14 \\
Ta Karamanlidika tou Fani & Athens & 1167 & 962 & 159 & 33 & 8 & 5 & 9.42 \\
Liondi Traditional Greek & Athens & 1096 & 916 & 124 & 34 & 15 & 7 & 9.40 \\
Restaurant & & & & & & & & \\
Oineas Restaurant & Athens & 888 & 712 & 125 & 41 & 7 & 3 & 9.32 \\
Avocado & Athens & 807 & 636 & 129 & 34 & 4 & 4 & 9.30 \\
Gods Restaurant & Athens & 738 & 421 & 200 & 65 & 22 & 30 & 8.25 \\
Smile Café Restaurant & Athens & 719 & 479 & 153 & 52 & 19 & 16 & 8.69 \\
Oroscopo & Athens & 687 & 552 & 107 & 19 & 5 & 4 & 9.36 \\
\hline
\end{tabular}

Table A10. Content generated by reviewers: 12 most frequent keywords.

\begin{tabular}{ccccccc}
\hline & \multicolumn{2}{c}{ Attractions } & \multicolumn{2}{c}{ Hotels } & \multicolumn{2}{c}{ Restaurants } \\
\cline { 2 - 7 } & Total: $\mathbf{9 , 2 4 2 , 5 3 6}$ & Unique: $\mathbf{5 4 , 4 0 9}$ & Total: $\mathbf{1 4 , 2 2 6 , 5 8 9}$ & Unique: $\mathbf{5 7 , 8 6 8}$ & Total: $\mathbf{8 , 3 3 2 , 3 3 0}$ & Unique: $\mathbf{5 4 , 5 1 1}$ \\
\cline { 2 - 6 } & Keyword & Count & Keyword & Count & Keyword & Count \\
\hline 1 & athens & 69,297 & hotel & 19,0608 & food & 92,552 \\
2 & tour & 49,202 & room & 96,628 & good & 61,763 \\
3 & great & 40,617 & great & 71,927 & great & 53,511 \\
4 & acropolis & 38,394 & good & 68,671 & place & 45,902 \\
5 & museum & 34,652 & staff & 67,189 & service & 45,279 \\
6 & time & 30,081 & breakfast & 63,328 & restaurant & 42,912 \\
7 & day & 28,535 & location & 62,276 & nice & 32,484 \\
8 & visit & 26,222 & athens & 60,205 & greek & 31,969 \\
9 & place & 22,889 & stay & 52,209 & athens & 31,438 \\
10 & history & 21,540 & rooms & 48,536 & best & 25,277 \\
11 & amazing & 20,890 & nice & 48,429 & excellent & 24,016 \\
12 & good & 20,444 & clean & 43,029 & friendly & 23,142 \\
\hline
\end{tabular}

\section{References}

1. Ritchie, J.R.B.; Crouch, G.I. The competitive destination: A sustainability perspective. Tour. Manag. 2000, 21, 1-7.

2. Ahmed, Z.U. The need for the identification of the constituents of a destination's tourist image: A promotion segmentation perspective. J. Prof. Serv. Mark. 1996, 14, 37-60.

3. Lynch, K. The Image of the City; The MIT Press: Cambridge, MA, 1960; ISBN 9780262120043.

4. Roth, K.P.; Diamantopoulos, A. Advancing the country image construct. J. Bus. Res. 2009, 62, 726-740. [CrossRef]

5. Gim, T.-H. Tourist satisfaction, image, and loyalty from an interregional perspective: An analysis of neighboring areas with distinct characteristics. Sustainability 2018, 10, 1283. [CrossRef]

6. Hunt, J.D. Image as a factor in tourism development. J. Travel Res. 1975, 13, 1-7. [CrossRef] 
7. Mayo, E.J. Regional images and regional travel development. In Proceedings of the Travel and Tourism Research Association Fourth Annual Conference, Salt Lake City, Utah, USA, 8-11 September 1973; pp. 211-217.

8. Gunn, C.A. Vacationscape: Designing Tourist Regions; Bureau of Business Research, University of Texas: Austin, TX, USA, 1972; ISBN 978-0877551614.

9. Chon, K.-S. The role of destination image in tourism: A review and discussion. Tour. Rev. 1990, 45, 2-9. [CrossRef]

10. Li, J.; Ali, F.; Kim, W.G. Reexamination of the role of destination image in tourism: An updated literature review. E-Rev. Tour. Res. 2015, 12, 191-209.

11. Pike, S. Destination image analysis: A review of 142 papers from 1973-2000. Tour. Manag. 2002, 23, 541-549. [CrossRef]

12. Echtner, C.M.; Ritchie, J.R.B. The meaning and measurement of destination image. J. Tour. Stud. 1991, 2, 2-12.

13. Zhang, H.; Fu, X.; Cai, L.A.; Lu, L. Destination image and tourist loyalty: A meta-analysis. Tour. Manag. 2014, 40, 213-223. [CrossRef]

14. Stepchenkova, S.; Mills, J.E. Destination image: A meta-analysis of 2000-2007 research. J. Hosp. Mark. Manag. 2010, 19, 575-609. [CrossRef]

15. Crompton, J.L. An assessment of the image of Mexico as a vacation destination and the influence of geographical location upon that image. J. Travel Res. 1979, 17, 18-23. [CrossRef]

16. Goodrich, J.N. The relationship between preferences for and perceptions of vacation destinations: Application of a choice model. J. Travel Res. 1978, 17, 8-13. [CrossRef]

17. Baloglu, S.; McCleary, K.W. A model of destination image formation. Ann. Tour. Res. 1999, $26,868-897$. [CrossRef]

18. Gartner, W.C. Image formation process. J. Travel Tour. Mark. 1993, 2, 191-215. [CrossRef]

19. Marine-Roig, E.; Ferrer-Rosell, B. Measuring the gap between projected and perceived destination images of Catalonia using compositional analysis. Tour. Manag. 2018, 68, 236-249. [CrossRef]

20. Sotiriadis, M.D. Sharing tourism experiences in social media: A literature review and a set of suggested business strategies. Int. J. Contemp. Hosp. Manag. 2017, 29, 179-225. [CrossRef]

21. Gkritzali, A.; Gritzalis, D.; Stavrou, V. Is Xenios Zeus still alive? Destination image of Athens in the years of recession. J. Travel Res. 2018, 57, 540-554. [CrossRef]

22. Garay Tamajón, L.; Cànoves Valiente, G. Barcelona seen through the eyes of TripAdvisor: actors, typologies and components of destination image in social media platforms. Curr. Issues Tour. 2017, 20, 33-37. [CrossRef]

23. Jabreel, M.; Moreno, A.; Huertas, A. Semantic comparison of the emotional values communicated by destinations and tourists on social media. J. Destin. Mark. Manag. 2017, 6, 170-183. [CrossRef]

24. Lalicic, L.; Huertas, A.; Moreno, A.; Jabreel, M. Which emotional brand values do my followers want to hear about? An investigation of popular European tourist destinations. Inf. Technol. Tour. 2019, 21, $63-81$. [CrossRef]

25. Huertas, A.; Marine-Roig, E. Differential destination content communication strategies through multiple Social Media. In Information and Communication Technologies in Tourism 2016; Springer International Publishing: Cham, Switzerland, 2016; pp. 239-252.

26. Deng, N.; Liu, J.; Dai, Y.; Li, H. Different cultures, different photos: A comparison of Shanghai's pictorial destination image between East and West. Tour. Manag. Perspect. 2019, 30, 182-192. [CrossRef]

27. Paül i Agustí, D. Characterizing the location of tourist images in cities. Differences in user-generated images (Instagram), official tourist brochures and travel guides. Ann. Tour. Res. 2018, 73, 103-115. [CrossRef]

28. Paül i Agustí, D. Tourist hot spots in cities with the highest murder rates. Tour. Geogr. 2019. [CrossRef]

29. Marine-Roig, E. Los "Travel Blogs" como objetos de estudio de la imagen percibida de un destino [Travel blogs as objects of study of the perceived destination image]. In Turismo y Tecnologías de la Información y las Comunicaciones; Guevara Plaza, A.J., Aguayo Maldonado, A., Caro Herrero, J.L., Eds.; Facultad de Turismo: Málaga, Spain, 2010; pp. 61-76. ISBN 9788460811152.

30. Gretzel, U.; Yoo, K.H. Use and impact of online travel reviews. In Information and Communication Technologies in Tourism 2008; O'Connor, P., Höpken, W., Gretzel, U., Eds.; Springer Vienna: Vienna, Austria, 2008; pp. 35-46.

31. TripAdvisor, About us. Available online: https://ripadvisor.mediaroom.com/us-about-us (accessed on 1 January 2019). 
32. Kwok, L.; Xie, K.L.; Richards, T. Thematic framework of online review research: A systematic analysis of contemporary literature on seven major hospitality and tourism journals. Int. J. Contemp. Hosp. Manag. 2017, 29, 307-354. [CrossRef]

33. Hlee, S.; Lee, H.; Koo, C. Hospitality and tourism online review research: A systematic analysis and heuristic-systematic model. Sustainability 2018, 10, 1141. [CrossRef]

34. Liang, T.-P.; Liu, Y.-H. Research landscape of business intelligence and big data analytics: A bibliometrics study. Expert Syst. Appl. 2018, 111, 2-10. [CrossRef]

35. Jelvehgaran Esfahani, H.; Tavasoli, K.; Jabbarzadeh, A. Big data and social media: A scientometrics analysis. Int. J. Data Netw. Sci. 2019, 145-164. [CrossRef]

36. Mashingaidze, K.; Backhouse, J. The relationships between definitions of big data, business intelligence and business analytics: a literature review. Int. J. Bus. Inf. Syst. 2017, 26, 488-505.

37. Rathore, A.K.; Kar, A.K.; Ilavarasan, P.V. Social media analytics: Literature review and directions for future research. Decis. Anal. 2017, 14, 229-249. [CrossRef]

38. Viñan-Ludeña, M.-S. A systematic literature review on social media analytics and smart tourism. In Smart Tourism as a Driver for Culture and Sustainability; Katsoni, V., Segarra-Oña, M., Eds.; Springer: Cham, Switzerland, 2019; pp. 357-374.

39. Pourkhani, A.; Abdipour, K.; Baher, B.; Moslehpour, M. The impact of social media in business growth and performance: A scientometrics analysis. Int. J. Data Netw. Sci. 2019, 3, 223-244. [CrossRef]

40. Centobelli, P.; Ndou, V. Managing customer knowledge through the use of big data analytics in tourism research. Curr. Issues Tour. 2019. [CrossRef]

41. Li, J.; Xu, L.; Tang, L.; Wang, S.; Li, L. Big data in tourism research: A literature review. Tour. Manag. 2018, 68, 301-323. [CrossRef]

42. Mariani, M.; Baggio, R.; Fuchs, M.; Höepken, W. Business intelligence and big data in hospitality and tourism: a systematic literature review. Int. J. Contemp. Hosp. Manag. 2018, 30, 3514-3554. [CrossRef]

43. Eurobarometer. Flash Eurobarometer 432: Preferences of Europeans Towards Tourism; European Commission: Brussels, Belgium, 2016.

44. VisitBritain Researching and Planning: Foresight-issue 150. Available online: https: //www.visitbritain.org/sites/default/files/vb-corporate/Documents-Library/documents/foresight_150_-_ researching_and_planning.pdf (accessed on 8 May 2019).

45. Analysts. The State of the American Traveler. Destinations Edition; Destination Analysts: San Francisco, CA, USA, 2018; Volume 27.

46. Marine-Roig, E. From the Projected to the Transmitted Image: The 2.0 Construction of Tourist Destination Image and Identity in Catalonia; Rovira i Virgili University: Vila-seca, Catalonia, Spain, 2014.

47. Andreu, L.; Bigné, J.E.; Cooper, C. Projected and perceived image of Spain as a tourist destination for British travellers. J. Travel Tour. Mark. 2000, 9, 47-67. [CrossRef]

48. Ayeh, J.K.; Au, N.; Law, R. Predicting the intention to use consumer-generated media for travel planning. Tour. Manag. 2013, 35, 132-143. [CrossRef]

49. Ayeh, J.K.; Au, N.; Law, R. “Do we believe in TripAdvisor?" Examining credibility perceptions and online travelers' attitude toward using user-generated content. J. Travel Res. 2013, 52, 437-452. [CrossRef]

50. Ukpabi, D.C.; Karjaluoto, H. What drives travelers' adoption of user-generated content? A literature review. Tour. Manag. Perspect. 2018, 28, 251-273. [CrossRef]

51. Yilmaz, B.S. Turkish tourism consumer's information search behavior: The role of user generated content in travel planning process. EcoForum 2017, 6, 1-6.

52. Mendes-Filho, L.; Mills, A.M.; Tan, F.B.; Milne, S. Empowering the traveler: an examination of the impact of user-generated content on travel planning. J. Travel Tour. Mark. 2018, 35, 425-436. [CrossRef]

53. Chong, A.Y.L.; Khong, K.W.; Ma, T.; McCabe, S.; Wang, Y. Analyzing key influences of tourists' acceptance of online reviews in travel decisions. Internet Res. 2018, 28, 564-586. [CrossRef]

54. Nilashi, M.; Ibrahim, O.; Yadegaridehkordi, E.; Samad, S.; Akbari, E.; Alizadeh, A. Travelers decision making using online review in social network sites: A case on TripAdvisor. J. Comput. Sci. 2018, 28, 168-179. [CrossRef]

55. Ritchie, J.R.B.; Crouch, G.I. A model of destination competitiveness and sustainability. In Destination Marketing and Management: Theories and Applications; Wang, Y., Pizam, A., Eds.; CABI: Wallingford, UK, 2011; pp. 326-339. 
56. Buhalis, D. Marketing the competitive destination of the future. Tour. Manag. 2000, 21, 97-116. [CrossRef]

57. Uysal, M.; Harrill, R.; Woo, E. Destination marketing research: Issues and challenges. In Destination Marketing and Management: Theories and Applications; Wang, Y., Pizam, A., Eds.; CABI: Wallingford, UK, 2011; pp. $99-112$.

58. Kladou, S.; Mavragani, E. Assessing destination image: An online marketing approach and the case of TripAdvisor. J. Destin. Mark. Manag. 2015, 4, 187-193. [CrossRef]

59. UNESCO Acropolis, Athens. Available online: https://whc.unesco.org/en/list/404 (accessed on 8 May 2019).

60. Fakeye, P.C.; Crompton, J.L. Image differences between prospective, first-time, and repeat visitors to the Lower Rio Grande Valley. J. Travel Res. 1991, 30, 10-16. [CrossRef]

61. Lai, K.; Li, X. Tourism destination image: Conceptual problems and definitional solutions. J. Travel Res. 2016, 55, 1065-1080. [CrossRef]

62. Manheim, J.B.; Albritton, R.B. Changing national images: International public relations and media agenda setting. Am. Polit. Sci. Rev. 1983, 78, 641-657. [CrossRef]

63. Bramwell, B.; Rawding, L. Tourism marketing images of industrial cities. Ann. Tour. Res. 1996, $23,201-221$. [CrossRef]

64. Boulding, K.E. The image: Knowledge in life and society; University of Michigan Press: Ann Arbor, MI, USA, 1956; ISBN 978-0472060474.

65. Bigné, J.E.; Sánchez, M.I.; Sánchez, J. Tourism image, evaluation variables and after purchase behaviour: inter-relationship. Tour. Manag. 2001, 22, 607-616. [CrossRef]

66. Pocock, D.; Hudson, R. Images of the Urban Environment; Macmillan: London, UK, 1978; ISBN 9780333192115.

67. Murphy, P.; Pritchard, M.P.; Smith, B. The destination product and its impact on traveller perceptions. Tour. Manag. 2000, 21, 43-52. [CrossRef]

68. Elliot, S.; Papadopoulos, N.; Szamosi, L. Studying place image: an interdisciplinary and holistic approach. Anatolia 2013, 24, 5-16. [CrossRef]

69. Um, S.; Crompton, J.L. Attitude determinants in tourism destination choice. Ann. Tour. Res. 1990, 17, $432-448$. [CrossRef]

70. Marine-Roig, E. Identity and authenticity in destination image construction. Anatolia Int. J. Tour. Hosp. Res. 2015, 26, 574-587. [CrossRef]

71. Marine-Roig, E. Measuring destination image through travel reviews in search engines. Sustainability 2017, 9, 1425. [CrossRef]

72. Phelps, A. Holiday destination image - the problem of assessment. An example developed in Menorca. Tour. Manag. 1986, 7, 168-180. [CrossRef]

73. Britton, R.A. The image of the Third World in tourism marketing. Ann. Tour. Res. 1979, 6, 318-329. [CrossRef]

74. Mathieson, A.; Wall, G. Tourism, Economic, Physical and Social Impacts; Longman: London, UK, 1982.

75. Wita, N.; Ashton, S.A. Tourist perception toward destination brand image sustainability: Mae Kam Pong Community case study. J. Int. Thai Tour. 2019, 14, 95-125.

76. Jiang, Y.; Ramkissoon, H.; Mavondo, F.T.; Feng, S. Authenticity: The link between destination image and place attachment. J. Hosp. Mark. Manag. 2017, 26, 105-124. [CrossRef]

77. Chi, C.G.-Q.; Qu, H. Examining the structural relationships of destination image, tourist satisfaction and destination loyalty: An integrated approach. Tour. Manag. 2008, 29, 624-636. [CrossRef]

78. Hernández-Lobato, L.; Solis-Radilla, M.M.; Moliner-Tena, M.A.; Sánchez-García, J. Tourism destination image, satisfaction and loyalty: A study in Ixtapa-Zihuatanejo, Mexico. Tour. Geogr. 2006, 8, 343-358. [CrossRef]

79. Wang, C.; Hsu, M.K. The relationships of destination image, satisfaction, and behavioral intentions: An integrated model. J. Travel Tour. Mark. 2010, 27, 829-843. [CrossRef]

80. Prayag, G.; Hosany, S.; Muskat, B.; Del Chiappa, G. Understanding the relationships between tourists' emotional experiences, perceived overall image, satisfaction, and intention to recommend. J. Travel Res. 2017, 56, 41-54. [CrossRef]

81. Agapito, D.; Oom do Valle, P.; da Costa Mendes, J. The cognitive-affective-conative model of destination image: A confirmatory analysis. J. Travel Tour. Mark. 2013, 30, 471-481. [CrossRef]

82. Han, H.; Kim, Y.; Kim, E.-K. Cognitive, affective, conative, and action loyalty: Testing the impact of inertia. Int. J. Hosp. Manag. 2011, 30, 1008-1019. [CrossRef]

83. Pike, S.; Ryan, C. Destination positioning analysis through a comparison of cognitive, affective, and conative perceptions. J. Travel Res. 2004, 42, 333-342. [CrossRef] 
84. Rapoport, A. Human Aspects of Urban Form; Pergamon Press: Oxford, UK, 1977.

85. Stern, E.; Krakover, S. The formation of a composite urban image. Geogr. Anal. 1993, 25, 130-146. [CrossRef]

86. Walmsley, D.J.; Lewis, G.J. People E Environment: Behavioural Approaches in Human Geography; Pearson Education Ltd.: London, UK, 1984.

87. Wakabayasi, Y. Behavioral studies on environmental perception by Japanese geographers. Geogr. Rev. Jpn. Ser. B 1996, 69, 83-94. [CrossRef]

88. Brijs, K.; Bloemer, J.; Kasper, H. Country-image discourse model: Unraveling meaning, structure, and function of country images. J. Bus. Res. 2011, 64, 1259-1269. [CrossRef]

89. Gallarza, M.G.; Gil Saura, I.; Calderón García, H. Destination image. Ann. Tour. Res. 2002, $29,56-78$. [CrossRef]

90. Beerli, A.; Martín, J.D. Factors influencing destination image. Ann. Tour. Res. 2004, 31, 657-681. [CrossRef]

91. Folgado-Fernández, J.A.; Hernández-Mogollón, J.M.; Duarte, P. Destination image and loyalty development: the impact of tourists' food experiences at gastronomic events. Scand. J. Hosp. Tour. 2017, 17, 92-110. [CrossRef]

92. Choe, J.Y.; Kim, S. Effects of tourists' local food consumption value on attitude, food destination image, and behavioral intention. Int. J. Hosp. Manag. 2018, 71, 1-10. [CrossRef]

93. Gartner, W.C. Temporal influences on image change. Ann. Tour. Res. 1986, 13, 635-644. [CrossRef]

94. Gartner, W.C.; Hunt, J.D. An analysis of state image change over a twelve-year period (1971-1983). J. Travel Res. 1987, 26, 15-19. [CrossRef]

95. Chon, K.-S. Tourism destination image modification process. Tour. Manag. 1991, 12, 68-72. [CrossRef]

96. Gerdt, S.-O.; Wagner, E.; Schewe, G. The relationship between sustainability and customer satisfaction in hospitality: An explorative investigation using eWOM as a data source. Tour. Manag. 2019, 74, 155-172. [CrossRef]

97. Gunasekar, S.; Sudhakar, S. How user-generated judgments of hotel attributes indicate guest satisfaction. J. Glob. Sch. Mark. Sci. 2019, 29, 180-195. [CrossRef]

98. Li, H.; Wang, C. (Renee); Meng, F.; Zhang, Z. Making restaurant reviews useful and/or enjoyable? The impacts of temporal, explanatory, and sensory cues. Int. J. Hosp. Manag. 2018. [CrossRef]

99. Vu, H.Q.; Li, G.; Law, R.; Zhang, Y. Exploring tourist dining preferences based on restaurant reviews. J. Travel Res. 2019, 58, 149-167. [CrossRef]

100. McKenzie, G.; Adams, B. A data-driven approach to exploring similarities of tourist attractions through online reviews. J. Locat. Based Serv. 2018, 12, 94-118. [CrossRef]

101. Hou, Z.; Cui, F.; Meng, Y.; Lian, T.; Yu, C. Opinion mining from online travel reviews: A comparative analysis of Chinese major OTAs using semantic association analysis. Tour. Manag. 2019, 74, 276-289. [CrossRef]

102. Song, S.; Kawamura, H.; Uchida, J.; Saito, H. Determining tourist satisfaction from travel reviews. Inf. Technol. Tour. 2019. [CrossRef]

103. Franzoni, S.; Bonera, M. How DMO can measure the experiences of a large territory. Sustainability 2019, 11, 492. [CrossRef]

104. Marine-Roig, E. Religious tourism versus secular pilgrimage: The basilica of La Sagrada Família. Int. J. Relig. Tour. Pilgr. 2015, 3, 25-37.

105. Marine-Roig, E.; Anton Clavé, S. A detailed method for destination image analysis using user-generated content. Inf. Technol. Tour. 2016, 15, 341-364. [CrossRef]

106. Marine-Roig, E.; Mariné Gallisà, E. Imatge de Catalunya percebuda per turistes angloparlants i castellanoparlants (Image of Catalonia perceived by English-speaking and Spanish-speaking tourists). Doc. Anàlisi Geogràfica 2018, 64, 219-245. [CrossRef]

107. Marine-Roig, E. Online travel reviews: A massive paratextual analysis. In Analytics in Smart Tourism Design: Concepts and Methods; Xiang, Z., Fesenmaier, D.R., Eds.; Springer: Heidelberg, Germany, 2017; pp. 179-202. ISBN 978-3-319-44262-4.

108. Genette, G. Paratexts: Thresholds of interpretation; Cambridge University Press: New York, NY, USA, 1997; ISBN 052141350.

109. Eurostat Tourism. Eurostat Regional Yearbook; Publications Office of the European Union: Luxembourg, 2018; pp. 139-150.

110. Marine-Roig, E. A webometric analysis of travel blogs and review hosting: The case of Catalonia. J. Travel Tour. Mark. 2014, 31, 381-396. [CrossRef] 
111. TripAdvisor Attica, Greece. Available online: https://www.tripadvisor.com/Tourism-g189399-AtticaVacations.html (accessed on 1 January 2019).

112. Roberts, C.W. Content Analysis. Int. Encycl. Soc. Behav. Sci. 2001, 2697-2702.

113. Stemler, S. An Overview of Content Analysis. Available online: https://pareonline.net/getvn.asp? $\mathrm{v}=7 \& \mathrm{n}=17$ (accessed on 8 May 2019).

114. Xiang, Z.; Du, Q.; Ma, Y.; Fan, W. A comparative analysis of major online review platforms: Implications for social media analytics in hospitality and tourism. Tour. Manag. 2017, 58, 51-65. [CrossRef]

(C) 2019 by the author. Licensee MDPI, Basel, Switzerland. This article is an open access article distributed under the terms and conditions of the Creative Commons Attribution (CC BY) license (http://creativecommons.org/licenses/by/4.0/). 